\title{
Skuteczne leczenie dazatynibem 18-letniej chorej na przewlekłą białaczkę szpikową oporną na imatynib w leczeniu 1. linii
}

\author{
Successful treatment with dasatinib of 18-years-old patient \\ with chronic myelogenous leukemia who relapsed \\ after the $1^{\text {st }}$-line therapy with imatinib
}

\author{
Ilona Seferyńska, Krzysztof Warzocha \\ Klinika Hematologii, Instytut Hematologii i Transfuzjologii, Warszawa
}

\begin{abstract}
Streszczenie
Przewlekła białaczka szpikowa (CML) jest rzadko rozpoznawanym nowotworem u dzieci i mtodych osób. Uważa się, że osoby poniżej 18 roku życia powinny być leczone z powodu CML tak, jak osoby doroste. Utrudnieniem jest jednak brak rejestracji inhibitorów kinazy tyrozynowej (TKI) II generacji w leczeniu chorych poniżej 18. roku zyycia w niektórych krajach, w tym w Polsce. Przedstawiono przypadek pacjentki, u której CML rozpoznano w 16. roku życia. Wdrożono leczenie imatynibem, ale byto nieskuteczne. $Z$ powodów formalnych nie byto możliwości wtaczenia TKI II generacji. Przeszczepienie allogenicznych krwiotwórczych komórek macierzystych również byto niemożliwe $z$ powodu braku dawcy. Kontynuowano podawanie imatynibu w zwiekszonej dawce, mimo ztej tolerancji leczenia. W 13. miesiacu od ustalonego rozpoznania chora osiagnęta petnoletność $i$ możliwe byto wtaczenie dazatynibu wedtug programu leczenia dla dorostych. Po 3 miesiacach leczenia uzyskano catkowita remisje cytogenetyczna i wieksza molekularna; podobny stan utrzymuje sie po 9 miesiacach.
\end{abstract}

Słowa kluczowe: przewlekła białaczka szpikowa, leczenie dzieci i młodzieży

Hematologia 2015; 6, 2: 209-212

\begin{abstract}
Children and adolescents rarely suffer from chronic myelogenous leukaemia (CML). Nonetheless, we assert that those aged below 18 years with this disease should be treated as adults, especially that in some countries (including Poland), official regulations still forbid treating such patients with $2^{\text {nd }}$ generation tyrosine kinase inhibitors (TKI). To support this view, we present a case study of a 16-year-old female patient with CML in whom initial treatment with imatinib had proved unsuccessful. She was thus prevented from receiving $2^{\text {nd }}$ generation TKI and also allogeneic haematopoietic stem cell transplantation was impossible, as a donor could not be found. Imatinib treatment was therefore continued at a higher dose, despite its poor tolerance. Thirteen months after diagnosis, the patient attained adulthood and thence an adult programme of dasatinib, treatment was initiated. After 3 months, complete cytogenic and major molecular remission was achieved and after 9 months this state of affairs has been maintained.
\end{abstract}

Key words: chronic myelogenous leukaemia, treatment for children and adolescents

Hematologia 2015; 6, 2: 209-212

Adres do korespondencji: Ilona Seferyńska, Klinika Hematologii, Instytut Hematologii i Transfuzjologii,

ul. Indiry Gandhi 14, 02-776 Warszawa, tel. 22349 63 34, e-mail: iseferynska@wp.pl 


\section{Wprowadzenie}

Przewlekła białaczka szpikowa (CML, chronic myelogenous leukemia) rzadko jest rozpoznawana u dzieci i osób poniżej 18. roku życia, stanowi 2-3\% białaczek u dzieci [1]. Utrudnia to przeprowadzenie badań klinicznych i opracowanie rekomendacji leczenia. Brakuje danych ilustrujących porównanie skuteczności i toksyczności leczenia przeszczepieniem allogenicznych krwiotwórczych komórek macierzystych (allo-HSCT, allogeneic hematopoietic stem cell transplantation) z przewlekłym leczeniem inhibitorami kinazy tyrozynowej (TKI, tyrosine kinase inhibitors). Autorzy dostępnych publikacji wskazują, że optymalnym leczeniem CML u dzieci jest leczenie za pomocą TKI według zasad ustalonych dla osób dorosłych przez ELN (European LeukemiaNet) [2, 3]. W rekomendacjach ELN nie różnicuje się sposobu leczenia zależnie od wieku chorego. Leczenie za pomocą allo-HSCT powinno być przeprowadzone u dzieci w przypadku niepowodzenia leczenia TKI II generacji [4]. W leczeniu dzieci i młodych osób w Polsce jest zarejestrowany imatynib jako leczenie I linii. W naszym kraju TKI II generacji nie mają rejestracji w leczeniu chorych poniżej 18. roku życia, co powoduje trudności formalne $z$ zastosowaniem tych leków w leczeniu młodych osób.

\section{Opis przypadku}

U 16-letniej uczennicy, dotychczas zdrowej, pod koniec 2012 roku wystąpiły: osłabienie, nietolerancja wysiłku fizycznego, senność, nadmierna potliwość, chudnięcie. Zauważyła także znaczne powiększanie się obwodu brzucha. $Z$ tego powodu zgłosiła się do lekarza rodzinnego. W wykonanej ambulatoryjnie morfologii krwi stwierdzono leukocytozę wynoszącą $248 \mathrm{G} / 1$, stężenie hemoglobiny równe $9,6 \mathrm{~g} / \mathrm{dl}$ oraz liczbę płytek krwi $984 \mathrm{G} / \mathrm{l}$, a w wykonanym badaniu ultrasonograficznym jamy brzusznej — splenomegalię $30 \mathrm{~cm}$ w osi długiej; 9 grudnia 2012 roku chorą skierowano do kliniki onkohematologii dziecięcej. W czasie przyjęcia do kliniki chora była w średnim stanie ogólnym; poza wymienionymi wyżej nieprawidłowościami stwierdzono wysoką aktywność dehydrogenazy mleczanowej (LDH, lactate dehydrogenase), wynoszącą $2573 \mathrm{j} . / 1$, stężenie kwasu moczowego równe $8,6 \mathrm{mg} / \mathrm{dl}$, w rozmazie krwi obwodowej natomiast: odsetek mieloblastów $-2 \%$, promielocytów $-10 \%$, mielocytów $-18 \%$, metamielocytów $-11 \%$, neutrofilów pałeczkowatych $-18 \%$, neutrofilów podzielonych $-28 \%$, eozynofilów
$-4 \%$, bazofilów $-6 \%$, limfocytów $-2 \%$, monocytów $-1 \%$, erytroblastów $-2 \%$. W mielogramie stwierdzono bogaty szpik z łącznym odsetkiem komórek układu granulocytowego wynoszącym 95\%. Badanie kariotypu wykazało obecność chromosomu Filadelfia (Ph, Philadelphia) w $91 \%$ badanych metafaz, w badaniu fluorescencyjnej hybrydyzacji in situ (FISH, fuorescence hybridization in situ) stwierdzono obecność genu fuzyjnego $B C R-A B L 1$ w $95 \%$ analizowanych jąder interfazowych, a badanie molekularne wykazało obecność genu hybrydowego $B C R-A B L 1$ (p210). Ustalono rozpoznanie CML $B C R-A B L 1$-dodatniej w fazie przewlekłej. Wskaźnik Sokala wynosił 0,65 (niski), wskaźnik Hasforda - 103,8 (niski). Przez kolejne 13 miesięcy, do czasu osiagnnięcia pełnoletności, chora pozostawała pod opieką ośrodka pediatrycznego.

Od 13 grudnia 2012 roku zlecono leczenie imatynibem w dawce $300 \mathrm{mg} / \mathrm{m}^{2}$, czyli $500 \mathrm{mg} /$ dobę. Leczenie było źle tolerowane przez chorą; odczuwała bóle kostno-mięśniowe o różnej lokalizacji, bóle zębów, głowy, nudności, senność. Po kilku tygodniach przyjmowania leku objawy niepożądane zmniejszyły się, ale nie ustąpiły całkowicie. $\mathrm{W}$ ocenie wykonanej po 3 miesiącach podawania imatynibu stwierdzano całkowitą remisję hematologiczną (CHR, complete hematologic response), brak odpowiedzi cytogenetycznej (CyR, cytogenetic response) (w kariotypie $-\mathrm{Ph}+\mathrm{w} 97 \%$ metafaz, w badaniu metodą FISH — fuzję BCR-ABL1 w $69 \%$ badanych jąder interfazowych), w badaniu molekularnym - obecność $21,4 \%$ transkryptu $B C R$ $-A B L 1$. Ten typ odpowiedzi, wedlug kryteriów ELN z 2009 roku, należy określić jako odpowiedź suboptymalną, a według kryteriów z 2013 roku jest to niepowodzenie leczenia. Zdecydowano wówczas o kontynuacji podawania imatynibu.

Po 6 miesiącach leczenia stwierdzono CHR, w kariotypie - w $93 \%$ metafaz obecny chromosom $\mathrm{Ph}+$, w badaniu metodą FISH w $50 \%$ analizowanych jąder interfazalnych - fuzję $B C R-A B L 1$, $\mathrm{w}$ badaniu molekularnym natomiast $-15,2 \%$ transkryptu $B C R-A B L 1$ w komórkach krwi obwodowej. Typ odpowiedzi, według kryteriów ELN z 2009 roku, oceniano jako niepowodzenie terapii. Kontynuowano jednak leczenie imatynibem. Chora nie ma rodzeństwa; została zakwalifikowana do allo-HSCT od dawcy niespokrewnionego i rozpoczęto procedurę poszukiwania dawcy. Po 9 miesiącach leczenia stwierdzono CHR, w kariotypie 88\% metafaz $\mathrm{Ph}+$, w badaniu metodą FISH w 56,5\% analizowanych jąder interfazalnych obecność fuzji $B C R-A B L 1$, w badaniu molekularnym zaś $36,2 \%$ transkryptu $B C R-A B L 1$ (w szpiku). Ze względu 
Tabela 1. Odpowiedź cytogenetyczna (kariotyp) i molekularna (metoda reakcji łańcuchowej polimerazy w czasie rzeczywistym) w czasie leczenia chorej inhibitorami kinaz tyrozynowych

Table 1. Cytogenetic (karyotype) and molecular (real-time quantitative polymerase chain reaction) response to tyrosine kinase inhibitors treatment of the patient

\begin{tabular}{|c|c|c|c|c|c|c|c|c|}
\hline \multirow[t]{2}{*}{ Rodzaj odpowiedzi } & \multicolumn{8}{|c|}{ Data badania } \\
\hline & $\begin{array}{c}11.12 . \\
2012\end{array}$ & $\begin{array}{l}4.03 \\
2013\end{array}$ & $\begin{array}{l}4.06 . \\
2013\end{array}$ & $\begin{array}{l}2.09 \\
2013\end{array}$ & $\begin{array}{l}9.12 . \\
2013\end{array}$ & $\begin{array}{c}28.04 . \\
2014\end{array}$ & $\begin{array}{c}28.07 \\
2014\end{array}$ & $\begin{array}{c}30.10 . \\
2014\end{array}$ \\
\hline $\begin{array}{l}\text { Odpowiedź cytogene- } \\
\text { tyczna (odsetek komórek } \\
\mathrm{Ph}+\text { ) }\end{array}$ & 91 & 97 & 93 & 88 & 15 & 0 & $\begin{array}{c}\text { Nie } \\
\text { badano }\end{array}$ & 0 \\
\hline $\begin{array}{l}\text { Odpowiedź molekularna } \\
\text { (ilość transkryptu } B C R \text { - } \\
\text {-ABL1 we krwi) }\end{array}$ & $\begin{array}{c}\mathrm{Nie} \\
\text { badano }\end{array}$ & 21,4 & 15,2 & $\begin{array}{c}36,5 \\
\text { (szpik) }\end{array}$ & $\begin{array}{c}2,43 \\
\text { (szpik) }\end{array}$ & 0,023 & 0,016 & 0,036 \\
\hline
\end{tabular}

na dotychczasowe niepowodzenie leczenia i brak innych dostępnych możliwości terapii (brak rejestracji w Polsce TKI II generacji w leczeniu chorych poniżej 18. rż.) podjęto decyzję o zwiększeniu dawki imatynibu do $500 \mathrm{mg} / \mathrm{m}^{2}$, czyli $900 \mathrm{mg}$ /dobę. Chora źle tolerowała tę dawkę, którą następnie zmniejszono do $800 \mathrm{mg}$ /dobę.

Po 12 miesiącach nadal utrzymywała się CHR, stwierdzono częściową remisję cytogenetyczną (PCyR, partial cytogenetic response) (w kariotypie 15\% metafaz $\mathrm{Ph}+$, w badaniu FISH 7\% komórek $\mathrm{z}$ fuzją $B C R-A B L 1)$, molekularnie redukcję ilości transkryptu $B C R-A B L 1$ do 2,433\% (badanie komórek szpiku). Nie stwierdzono mutacji KD (kinase domain) BCR-ABL1. Taką odpowiedź po 12 miesiącach, według kryteriów ELN z 2009 roku, oceniano jako niepowodzenie terapii. Nie znaleziono również niespokrewnionego dawcy szpiku kostnego.

W styczniu 2014 roku chora ukończyła 18 lat i została skierowana do Poradni Hematologicznej Instytutu Hematologii i Transfuzjologii; 19 stycznia 2014 roku u pacjentki wdrożono leczenie TKI II generacji dazatynibem w dawce $100 \mathrm{mg} /$ dobę. Tolerancja leczenia była bardzo dobra. Po 3 miesiącach leczenia stwierdzono CHR, CCyR i większą odpowiedź molekularną (MMR, major molecular response) $(0,023 \%$ BCR-ABL1). Po 6 miesiącach leczenia dazatynibem stwierdzano utrzymywanie się CHR i MMR (0,016\% BCR-ABL1). Po 9 miesiącach nadal stwierdza się CCyR i MMR (tab. 1). Leczenie dazatynibem jest kontynuowane.

\section{Dyskusja}

Przewlekła białaczka szpikowa u dzieci i osób młodych, poniżej 18. roku życia, to nowotwór rzadko rozpoznawany; w Stanach Zjednoczonych zachorowalność wynosi 1/mln osób poniżej 20. roku życia, przy czym najniższa jest u dzieci poniżej 4. roku życia $[1,5]$. Przed erą TKI standardem leczenia dzieci chorych na CML było allo-HSCT. $\mathrm{W}$ badaniach retrospektywnych wykazano, że po allo-HSCT od dawców spokrewnionych, wykonanych w latach 1982-2004, 3-5-letnie okresy wolne od zdarzeń (EFS, event-free survival) uzyskano u 61-63\%, a całkowite przeżycia (OS, overall survival) wynosiły $66-87 \%$. W odniesieniu do allo-HSCT od dawców niespokrewnionych wyniki były nieco gorsze: EFS - 27-55\%, OS - 45-65\% [6-9]. Należy pamiętać, że leczenie za pomocą allo-HSCT u dzieci wiąże się z ryzykiem licznych powikłań, $\mathrm{w}$ tym odległych, takich jak upośledzenie wzrostu, rozwoju, niepłodność, niebezpieczeństwo rozwoju wtórnych nowotworów.

Według rekomendacji ELN z 2009 roku, obowiązujących w czasie rozpoznania CML u pacjentki, leczeniem I linii w fazie przewlekłej CML był imatynib, niezależnie od wieku chorego. W leczeniu II linii zalecano dazatynib lub nilotynib, natomiast allo-HSCT rekomendowano w przypadku niepowodzenia terapii II linii lub wcześniej w przypadku transformacji blastycznej lub zaostrzenia białaczki. Wyznaczono również punkty czasowe dla oceny, prognozowania skuteczności leczenia i ewentualnej zmiany leczenia - po 3, 6, 12 i 18 miesiącach, a następnie, co 3 miesiące [2]. Podstawą powyższych opracowań były badania kliniczne przeprowadzonych w populacji osób starszych.

Wykazano dużą skuteczność imatynibu w leczeniu I linii, również u osób poniżej 18. roku życia. Około 150 dzieci leczono imatynibem w ramach różnych badań klinicznych, uzyskując CHR u 96\%, a CCyR - u 69\% po 12 miesiącach [9-11]. Do badania grupy francuskiej (French CML IV study) włączono 44 dzieci w fazie przewlekłej choroby; u $86 \%$ uzyskano CHR) po 3 miesiącach, u $62 \%$ - CCyR 
po 12 miesiącach i całkowitą odpowiedź molekularną (CMR, complete molecular response) - u $31 \%$ chorych po 12 miesiącach [12, 13]. Najczęściej stwierdzanymi objawami niepożądanymi były neutropenia i upośledzenie wzrostu u leczonych dzieci [12]. Ustalono dawkę początkową w leczeniu chorych poniżej 18. roku życia: w fazie przewlekłej - 260-300 mg/m² (maks. $400 \mathrm{mg} / \mathrm{d}$.), w fazie zaostrzenia $-400 \mathrm{mg} / \mathrm{m}^{2}$ (maks. $600 \mathrm{mg} / \mathrm{d}$.), a w fazie transformacji blastycznej $-500 \mathrm{mg} / \mathrm{m}^{2}$, maksymalnie $800 \mathrm{mg} /$ dobę. Doniesienia o leczeniu dzieci chorych na CML dazatynibem są nieliczne. W badaniu 1. fazy Children's Oncology Group podano dazatynib 39 dzieciom $z$ opornymi nowotworami, w tym białaczkami. U 8 chorych na CML uzyskano odpowiedź cytogenetyczną, w tym u $3 \mathrm{CCyR}$ i u 3 PCyR [14]. Obecnie są prowadzone badania 2. fazy. Doświadczenia $z$ leczeniem nilotynibem są jeszcze bardziej ograniczone - dotyczą głównie leczenia dzieci chorych na ostrą białaczką limfoblastyczną (ALL, acute lymphoblastic leukemia) i z przełomem blastycznym CML.

Dotychczasowe wyniki badań $z$ zastosowaniem TKI w leczeniu chorych na CML w wieku poniżej 18 lat wskazują na podobnie wysoką skuteczność i niedużą toksyczność leczenia oraz przewage leczenia TKI nad allo-HSCT. Brakuje badań, w których porównano by obie metody leczenia, i $z$ wielu względów trudno takie badania przeprowadzić. Przy podejmowaniu decyzji o leczeniu należy również uwzględniać wiek dziecka, ponieważ inne będą konsekwencje leczenia dziecka przed okresem dojrzewania, a inne - u osoby po pokwitaniu.

\section{Podsumowanie}

Opisana chora w chwili rozpoznania CML miała 16 lat; fizycznie była już osobą dojrzałą, jednak konieczne było zastosowanie schematu leczenia obowiązującego dla osób poniżej 18. roku życia. Pacjentce podawano imatynib w dawce $500 \mathrm{mg} / \mathrm{m}^{2} /$ dobę. Leczenie to źle tolerowała. Po kolejnych 3, 6 i 9 miesiącach nie uzyskano satysfakcjonującej odpowiedzi na leczenie. Chora nie miała rodzinnego ani niespokrewnionego dawcy szpiku, a więc nie było możliwe przeprowadzenie procedury allo-HSCT. Zwiększenie dawki imatynibu nie spowodowało optymalnej odpowiedzi po kolejnych 3 miesiącach leczenia, nasiliło natomiast objawy niepożądane. Dopiero ukończenie przez pacjentkę 18 lat i możliwość leczenia według programów leczenia zarejestrowanych dla dorosłych umożliwiło zastosowanie TKI II generacji — dazatynibem. Terapia ta była i jest dobrze tolerowana; po 3 mie- siącach uzyskano CCyR i MMR. Po 9 miesiącach ten stan się utrzymuje.

Przypadek opisanej pacjentki wskazuje na potrzebę ustalenia rekomendacji dotyczących leczenia dzieci i młodzieży z rozpoznaniem CML i zwiększenia dostępności TKI II generacji dla tej grupy wiekowej. Procedura allo-HSCT powinna być stosowana po niepowodzeniu leczenia za pomocą TKI II generacji albo w fazie akceleracji lub transformacji białaczki, podobnie jak u dorosłych chorych.

\section{Piśmiennictwo}

1. Suttorp M., Millot F. Treatment of pediatric chronic myeloid leukemia in the year 2010: use of tyrosine kinase inhibitors and sttem-cell transplantation. Hematology Am. Soc. Hematol. Educ. Program 2010: 368-376.

2. Baccarani M., Deininger M.W., Rosti R. i wsp. Chronic myeloid leukemia: an update of concepts and management recommendations of European LeukemiaNet. J. Clin. Oncol. 2009; 35: 6041-6061 .

3. Baccarani M., Deininger M.W., Rosti G. i wsp. European LeukemiaNet recommendations for the management of chronic myeloid leukemia: 2013. Blood 2013; 122: 872-884.

4. Suttorp M., Yaniv I., Schultz K.R. Controversies in the treatment of CML in children and adolescens: TKIs versus BMT? Biol. Blood Marrow Transplant. 2011; 17: S115-S122.

5. Fuente J., Baruchel A., Biondi A. i wsp. Managing children with chronic myeloid leukaemia (CML). Recommendations for the management of CML in children and young people up to the age of 18 years. Br. J. Haematol. 2014; 167: 33-47.

6. Millot F., Esperou H., Bordigoni P. i wsp. Allogeneic bone marrow transplantation for chronic myeloid leukemia in childhood: a report from the Société Française de Greffe de Moelle et de Thérapie Cellulaire (SFGM-TC). Bone Marrow Transplant. 2003; 32: 993-999.

7. Cwynarski K., Roberts I.A., Iacobelli S. i wsp. Stem cell transplantation for chronic myeloid leukemia in children. Blood 2003; 102: 1224-1231.

8. Suttorp M., Claviez A., Bader P. i wsp. Allogeneic stem cell transplantation for pediatric and adolescent patients with CML: results from the prospective trial CML-paed I. Clin. Pediatr. 2009; 221: 351-357.

9. Andolina J.R., Neudorf S.M., Corey S.J. i wsp. How I treat childhood CML? Blood 2012; 119: 1821-1830.

10. Suttorp M., Thiede C., Tauer J.T. i wsp. Chronic myeloid leukemia in pediatrics - first results from study CML-PAED II. Blood 2009; 114: 145.

11. Millot F., Guilhot J., Nelken B. i wsp. Imatynib mesylate is effective in children with chronic myelogenous leukemia in the late chronic and advanced phase, and in the relapse after stem cell transplantation. Leukemia 2006; 20: 187-192.

12. Millot F., Baruchel A., Guilhot J. i wsp. Imatinib is efficient but has a negative impact on growth in children with previously untreated chronic myeloid leukemia (CML) in early chronic phase (CP) results of the French national phase IV trial. Blood 2009; 110: abstrakt 863.

13. Millot F., Baruchel A., Guilhot J. i wsp. Imatinib is effective in children with previously untreated chronic myelogenous leukemia in early chronic phase: results of the French national phase IV trial. J. Clin. Oncol. 2011; 29: 2827-2832.

14. Aplenc R., Blaney S.M., Strauss L.C. i wsp. Pediatric phase I trial and pharmacokinetic study of dasatinib: a report from the children's oncology group phase I consortium. J. Clin. Oncol. 2011; 29: 839-844. 